\title{
Biochemical Analysis and Mineral Composition of Methanolic Extract of Astragalus Gummifer
}

\author{
Hamsa Noreen ${ }^{1,2}$, Madeeha ${ }^{2}$, Rukhshanda ${ }^{2}$ Zarmina $^{2}$, Rozina Khattak ${ }^{2}$, Aaliya Minhas ${ }^{2}$, Maryam Jan ${ }^{1}$, \\ Waseem Hassan ${ }^{1 *}$ \\ ${ }^{1}$ Institute of Chemical Sciences, University of Peshawar, Peshawar, Khyber Pakhtunkhwa, Pakistan \\ ${ }^{2}$ Department of Chemistry, Shaheed Benazir Bhutto Women University, Peshawar, Khyber Pakhtunkhwa, Pakistan \\ *Corresponding author: Waseem Hassan, Institute of Chemical Sciences, University of Peshawar, Peshawar, Khyber \\ Pakhtunkhwa, Pakistan
}

\begin{tabular}{|c|c|}
\hline ARTICLE INFO & ABSTRACT \\
\hline 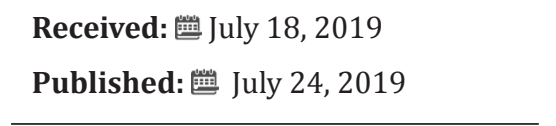 & $\begin{array}{l}\text { Traditionally, gum obtained from Astragalus gummifer are consumed as analgesic } \\
\text { agent. Current study focused on the proximate, phytochemical and elemental analysis of } \\
\text { methanolic extract of A. gummifer. In proximate analysis different nutritional constitutes }\end{array}$ \\
\hline $\begin{array}{l}\text { Citation: Hamsa Noreen, Madeeha } \\
\text { Rukhshanda, Zarmina, Rozina Khattak, } \\
\text { Aaliya minhas, Maryam Jan, Waseem } \\
\text { Hassan. Biochemical Analysis and Min- } \\
\text { eral Elements Composition of Metha- } \\
\text { nolic Extract of Astragalus Gummifer. } \\
\text { Biomed J Sci \& Tech Res 20(1)-2019. } \\
\text { BJSTR. MS.ID.003387. }\end{array}$ & $\begin{array}{l}\text { like moisture, ash and total acidity in methanolic extract of } A \text {. gummifer was detected. In } \\
\text { proximate screening highest ratio of ash }(35.1 \pm 2.0 \%) \text { indicating a richest bio-resource of } \\
\text { vitamins. While the values for moisture }(13.5 \pm 1.10 \%) \text { and total acidity }(0.009 \pm 0.0001 \%) \\
\text { indicating its valuable properties. Phytochemical screening was implemented for the } \\
\text { identification of different bioactive compounds i.e. tannins, flavonoids, gum and mucilage, } \\
\text { phenols, saponins, protein \& amino acid, alkaloids in methanolic extract of } A \text {. gummifer. } \\
\text { The results indicated that flavonoids, phenolic compounds, proteins \& amino acids and } \\
\text { gum \& mucilage were present in the extract while saponins and tannins were not found. } \\
\text { Mettalic screening was carried out for the quantification of different mineral elements i.e. }\end{array}$ \\
\hline $\begin{array}{l}\text { Keywords: Medicinal Plant; A. Gum- } \\
\text { mifer; Metallic Screening; Phytochemi- } \\
\text { cal Compounds; Proximate Analysis }\end{array}$ & $\begin{array}{l}\mathrm{Fe}, \mathrm{Mn}, \mathrm{Zn}, \mathrm{Cr}, \mathrm{Cu} \text { and } \mathrm{Ni} \text {. The highest ratio was documented for } \mathrm{Ni}(8.69 \mathrm{ppm}) \text { followed } \\
\text { by ( } 4.73 \mathrm{ppm}) \text { for } \mathrm{Cr} \text {. The lowest concentration was found for } \mathrm{Mn} \text { measuring ( } 5.30 \mathrm{ppm}) \\
\text { while the values for Fe and Zn were recorded as ( } 6.50 \mathrm{ppm} \text { and } 6.04 \mathrm{ppm}) \text { respectively. The } \\
\text { results obtained in this study clearly indicated that methanolic extract of } A \text {. gummifer is } \\
\text { the rich source of secondary metabolites and certain mineral elements which support the } \\
\text { use of this plant as stabilizing agent in the food, textile, leather, pharmaceutical, cosmetic } \\
\text { and industries. }\end{array}$ \\
\hline
\end{tabular}

\section{Introduction}

Essential metals are valuable and show a unique role in the functional and structural integrity of the organization of living systems. Even though minerals encompass only $4-6 \%$ of the human body and do not play a part proficiently in fulfilling the energy necessities, however their significance can be recognized from their participation in a large number of physicochemical processes of supreme significance which occurs incessantly in living organisms $[1,2]$. Furthermore, minerals are generally classified as micro (zinc $(\mathrm{Zn})$, manganese $(\mathrm{Mn})$, magnesium $(\mathrm{Mg})$, potassium $(\mathrm{K})$, iron $(\mathrm{Fe})$, copper $(\mathrm{Cu})$, chromium $(\mathrm{Cr})$ and cobalt (Co)) or macro (calcium $(\mathrm{Ca})$, sodium $(\mathrm{Na})$, chlorine $(\mathrm{Cl})$ and phosphorus $(\mathrm{P})$ ) elements that generally depend on their requirements to the body and it has been found that approximately more than $100 \mathrm{mg} / \mathrm{dl}$ of the macronutrients and less than $100 \mathrm{mg} / \mathrm{dl}$ of the micronutrients are essential on daily basis $[3,4]$. Insufficiencies of the mineral elements are the prime public health problem in lots of underdeveloped countries with women and infants [5]. Researchers have exposed that brutal cases of anemia most likely because of mineral deficiencies are a direct cause of child and maternal mortality. The herbal medicines are the best source of these fundamental minerals which can be consumed both for nutritional and therapeutic purposes [6].

Astragalus gummifer (Labill.) belongs to the family Fabaceae, is a naturally producing complex, synthesized from the shrubs of 
the Astragalus plant and is commonly known as gond katira. Gum tracaganth is a native shrub found in arid regions of the eastern Mediterranean and South Western Asia [7]. Literature reported that Tragacanth gum could be used as laxative, antitussive, antidiarrheic and as an aphrodisiac. Moreover, it is used as a binding agent in the formation of capsules, prescriptions and tablets, as an emulsifying agent in the production of creams, balms as an adhesive agent in pastes and as a thickener in the formulation of cosmetics, toothpastes, syrups, jellies, mayonnaise, salad dressings, sauces, liqueurs, candy and ice creams [8]. Literature further exposed that most of edible gum obtained from Astragalus genus has an extensive variety of applications in the pharmaceutical [9], cosmetic [10], and food industries [11-13], as a thickening emulsifying and gelling agent as they produce gel like viscous solution when added in water. In addition, pharmaceutical uses of gums as formulary mediator, the polysaccharides present in these gums also have potential biological actions [14,15]. Different polysaccharides contain various immunomodulatory properties depending on its structure including antioxidant [16], anticoagulant [17], hypocholesterolemic [18], antiviral [19], anti-inflammatory [20,21], keratinocytes, DNA repair [22] and antitumor [23-25] properties.

Furthermore, scientist performed an experiment on mice culture which is infested by Punta Toro Virus (PTV), Tragacanth in polysaccharides were introduced in the infected mice. The presence of these polysaccharides protected the majority of mice from mortality by activating the murin peritoneal macrophages, which proves that A. gummifer act as an immunomodulators and inhibit the multiple growth of cancer cells and viruses [26]. General survey highlighted that A. gummifer shows a potent allergenic effect and causing severe allergic responses. Further studies demonstrated that oral consumption or ingestion causes severe reactions. The immunogenicity of A. gummifer was established in mice that show cell- interceded immunity by performing swelling a test upon foot pad. Sanitization of the gum contended to a distinct decrease of the immune reaction [27]. No adverse effects were observed from hematological measurements and histological studies [28]. Moreover, plants gums are derivatives of different polysaccharides with a large number of biological activities and pharmaceutical applications. A small number of researches have focused on physicochemical properties of gums obtained from different plants especially that the gums which are available in herbal market are mixture of exudates obtained from different species. It is important to determine the physicochemical properties specifically metallic content of gum exudates obtained from different species of Astragalus genus to improve its biological application. Therefore, in current study we for the first time determined the elemental analysis of A. gummifer.

\section{Materials and Methods}

\section{Sample Collection and Identification}

The plant was selected from the local market of Peshawar, identified at the Shaheed Benzir Bhutto Women University Peshawar
(Khyber Pakhtoonkwha, Pakistan) and kept in polyethylene bags till analysis.

\section{Nutritional Profile}

The nutritional profile i.e. ash, moisture and total acidity of methanolic extract of A. gummifer was determined using the standard methods of Association of Official Analytical Chemist (AOAC) [29].

\section{Phytochemical Screening}

Phytochemical screening was performed for the identification of tannins, flavonoids, alkaloids, saponins, phenols, amino acids in the methanolic extract of A. gummifer by the standard methods of Association of Official Analytical Chemist [30].

\section{Metallic Screening}

Extract Preparation: A. gummifer extract was analyzed by Atomic absorption spectroscopy and dried in an oven at $70^{\circ} \mathrm{C}$ for 24 hours [31].

Digestion of Sample: A. gummifer (1g) was put in a porcelain crucible; the crucible was placed in a muffle furnace at $500^{\circ} \mathrm{C}$ for overnight. After this, the ash was then put in the $5 \mathrm{~mL}$ flask by adding $20 \% \mathrm{HCL}$, followed by warming the solution through an acid necessary to dissolve the residue. After digestion the solution was then subjected to a filter paper washed by an acid for filtration and pour into a $50 \mathrm{~mL}$ flask. Finally, the filtered solution was then diluted by adding deionized water in it and shakes the solution well.

\section{Results and Discussion}

\section{Nutritional Profile}

The nutritional profile (ash, moisture and total acidity) of methanolic extract of A. gummifer in percent is given in (Figure 1). The calculated percentage of moisture content was (13.57 $\pm 1.10 \%)$ and the ash content was $(92.3 \pm 3.38 \%)$. Similarly, the calculated value for total acidity was $(0.009 \pm 0.0001 \%)$. The proximate data of the A. gummifer provides valuable information about the prevalence and extent of macro elements which are mandatory for adequate ingestion of nutrients, normal physiological actions of human body and most frequently applicable for the elimination of illnesses. Nutritional profile of the methanolic extract of $A$. gummifer is given in Figure 1. In proximate analysis different compositions of nutritional constituents are studied. Highest ratio of ash $(35.1 \pm 2.0 \%)$ shows that it is a richest source of minerals. While the moisture and total acidity shows valuable and reasonable association with their factors i.e. pressure, temperature and humidity. In the nutritional index the ash value is the total amount of inorganic material existing in the sample which are formed after the process combustion; hence illustrated the existence of greater amounts of organic components in the low ash values [32]. Furthermore, the presence of Ashes in the plant indicates the concentration of mineral elements in the plants which may affect the pharmacological activities of plant [33] 


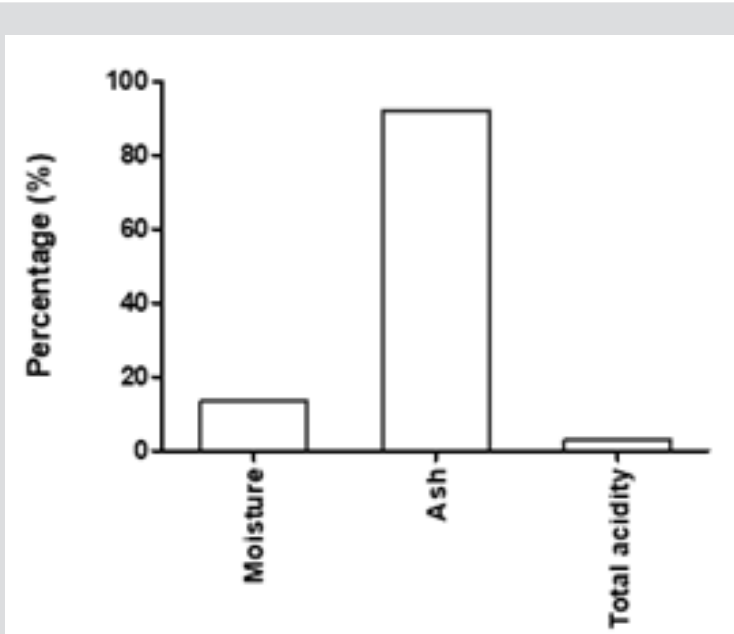

Figure 1: Nutritional profile of methanolic extract of A. gummifer.

In addition, moisture can be influenced byvarious environmental factors such as temperature, climate, humidity and harvest time as well as storage situation. Thus, it is important for nutritional scientist to quantify reliably the moisture contents [34]. The high moisture value indicates the amount of total solids and their short lifespan [35]. Low acidity value indicated that the plant do not have any aggressive effects and proves its safety and efficacy towards humans. The results achieved in the current study estimated that these plants are important for minerals consumption and energy requirements.

\section{Phytochemical Screening}

The phytochemicals (alkaloids, flavonoids, phenolic compound, protein \& amino acid, saponines, tannins and gum \& mucilage) were detected in methanolic extracts of A. gummifer as shown in Table 1. The results of $A$. gummifer indicated that flavonoids, phenolic compounds, proteins $\&$ amino acids and gum \& mucilage were present in the extract while saponins and tannins were absent. In phytochemical analysis important secondary metabolites are studied as displayed in Table 1. Tannins are important, natural polyphenolic compound, having high molecular weights. Tannic acid is oxidized form of tannin that is accounted for scavanging $\bullet \mathrm{OH}$ radical, it also inhibits 2-deoxyribose (peroxidative enzyme) and causes oxidative degradation influenced by $\bullet \mathrm{OH}$ radicals, created from Fenton reagents [36]. In addition, it has capability to chelate trace metals like Fe (II) and cause the formation of complexes [37]. Furthermore, tannin also possess hydroxyl functional group which is responsible for confiscating heavy metal ions. Proanthocyanidine and flavan-3ol monomers are the types of condensed tannin that have been indicated for lowering plasma cholesterol levels, prevent LDL oxidation and activate eNOS to inhibit blood clot formation [38].

Table 1: Qualitative analysis of the photochemical of methanolic extract of A. gummifer.

\begin{tabular}{|c|c|c|}
\hline S\# & Phytoconstituent & Astragalus Gummifer \\
\hline 1. & Alkaloid & - \\
\hline 2. & Saponins & + \\
\hline 3. & Phenolic compound & + \\
\hline 4. & Flavonoids & + \\
\hline 5. & Protein \& amino acid & - \\
\hline 6. & Tannins & + \\
\hline
\end{tabular}

Similarly, flavonoids are a polyphenolic compound, naturally present in plants as secondary metabolites and have ability to perform important biological actions [39]. Flavonoids are also reported to inhibit NADPH oxidase activity, which are known to generate considerable amounts of $\mathrm{O}_{2}$ radicals by phagocytes. Literature reported the in vitro vascular NADPH oxidase inhibition activity by a flavonoid derivative [40]. Flavonoids exhibit antioxidant efficacy via reinforcement of cellular antioxidants and are shown to act as intermediary antioxidants in the protection of lipophilic antioxidants (ubiquinol, vitamin E) and also endangered by hydrophilic antioxidants such as ascorbic acid [41]. The phenolic compounds are one of the major and most permeating groups of plants metabolites [42]. Phenols are known as antiinflammatory agents, as natural antioxidants, effective against cardiac pathologies, potent anticancer agents and are also used as nutraceuticals [43]. They show biological activities like antiaging, enhancement of endothelial capacity, anti-apoptosis as well as embarrassment of cell proliferation activities and angiogenesis
[44]. Proteins are important ingredients of cells; thus they are extensively important for human health. Literature revealed that protein-calorie malnutrition deficiency is a chief aspect accountable in dietary pathology [45]. The protein energy malnutrition (PEM) is considered as the main factor in development of various nutritional pathologies including kwashiorkor, marasmus or a combination of the two (marasmic-kwashiorkor). Thus, these results help in sorting the plants having high protein values and also encourage their uses in diet [46].

\section{Metallic Content}

The quantifiable mineral composition of A. gummifer shrubs was performed by atomic absorption spectrophotometer (AAS) for detection and estimation of metals including $\mathrm{Fe}, \mathrm{Mn}, \mathrm{Zn}, \mathrm{Cr}, \mathrm{Cu}$ and $\mathrm{Ni}$ as presented in Figure 2, which estimated that the evaluated elements were present in different fractions. The highest ratio was documented for $\mathrm{Ni}$ (84.69 ppm) followed by (41.73 ppm) of Cr. The lowest concentration was found for Mn measuring (5.30 ppm) while 
the values for Fe and $\mathrm{Zn}$ were measured as (6.50 ppm and 6.04 ppm) respectively. Literature reported that $\mathrm{Fe}$ is a major constituent of hemoglobin and transferrin which is present in the blood cells and in plasma portions of the blood, respectively. Iron is also present in various portions of hemoglobin, myoglobin and cytochromes, and also serve as a succinate dehydrogenase as well as a co-factor for enzymes which take part in the production of neurotransmitters [47]. The deficiency of Fe in man causes weakening in development of brain, restive legs syndrome and organogenesis [48]. High intake of Fe in many body parts like tissues and organs as well as central nervous system subsequent in diseases like Parkinson's disease, haemosiderosis, Alzheimer's disease, type-1 neurodegeneration $[49,50]$. Besides, Fe in the body play an essential role as it transfers oxygen from lungs to the hemoglobin and various tissue cells [51]. Furthermore; its deficiency is the most inclusive nutritional discrepancy in person's resultant from minor intake of Fe in diet [52].

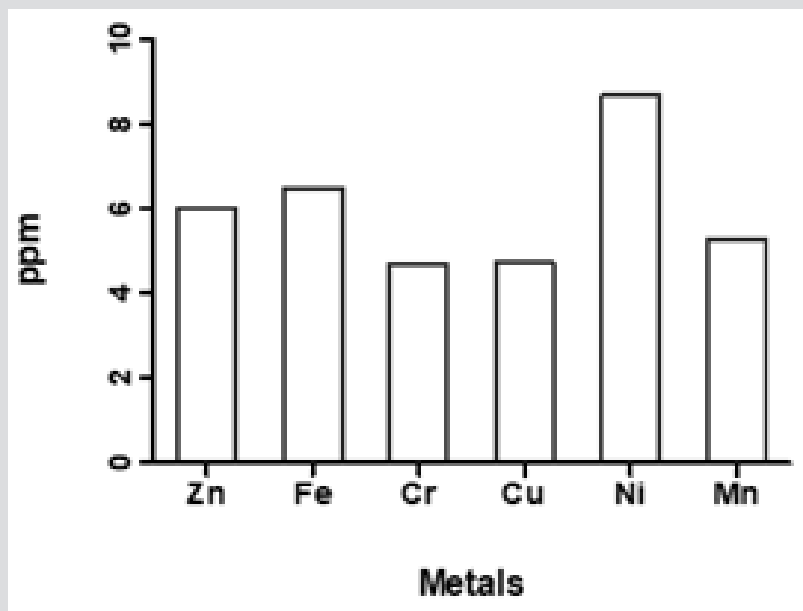

Figure 2: Metallic content of methanolic extract of A. gummifer.

According to FAO/WHO the permitted value for Cr suggested as 2 ppm for every individuals [53], which has closeness with the mean value of $\mathrm{Cr}$ in all the plants, which is \pm 4 . Several studies reported that $\mathrm{Cr}$ is an imperious constituent of glucose tolerance factor (GTF) and effective component of carbohydrate metabolism, which increases the functions of insulin and endures tolerance of normal glucose level [54]. Deficiency of Cr causes certain diseases like atherosclerosis, hyperglycemia and cataracts. Human and animal study shows that $\mathrm{Cr}$ is helpful in regulation of RNA and also significant in the metabolism of lipids and proteins. Increase concentration of $\mathrm{Cr}$ causes toxicological effect in body tissues and also reduces the proper functioning of kidney, central nervous system, liver and blood and finally causes death of individuals [55]. Furthermore, the permitted level of $\mathrm{Cu}$ in diet is suggested as $900 \mathrm{mg}$ for kids and adult persons. $\mathrm{Cu}$ is a significant redoxactive constituent and a vital component of various organizations of enzyme comprising lactase, ceruloplasmin, cytolic superoxide dismutase cytochrome oxidase. The important role of $\mathrm{Cu}$ is to assists the absorption and assimilation of Fe content in hemoglobin, and hence regulates the production of insulin while its deficit can cause disease like anemia [56]. $\mathrm{Cu}$ is also essential and active in the even functioning of hematologic and neurologic systems. But, additional intake of $\mathrm{Cu}$ in diet cause accumulation of $\mathrm{Cu}$ contents in liver which is effective in $\mathrm{Cu}$ poisoning deterioration in blood hematologic rate and $\mathrm{Cu}$ poisoning. It also unfavorably influences the regular activities of liver and most significantly causes jaundice owed to erythrocyte hemolysis [57].

Similarly, the permitted level for intake of Nickel (Ni) should be $0.006 \mathrm{ppm}$. Literature showed that Ni plays important role in the metabolic activities of nucleic acids, protection of the structure of membrane, regulator of prolactin and function as a basic component of plant enzymes such as hydrogenases and several ureases. Ni is usually found in the pancreas and reliefs in regulation of insulin whereas its deficiency causes certain disorders in liver [58]. Manganese (Mn) is an essential component of various biochemical processes and enzymes such as hydrolyses decarboxylases and transferases. Literature reported that $\mathrm{Mn}$ is effective in treatment of diabetes mellitus. Optimal level of Mn sustains the organization of normal bone and control the proper activities of central nervous system (CNS), while at low concentration they cause reproductive failure in both genders. Moreover, Mn toxicity results in severe influences on Central Nervous System and attitude $[59,60]$.

\section{Conclusion}

Current study highlights the significance of mineral composition, phytochemical constituents, and nutritional profile of $A$. gummifer, which confirmed that A. gummifer an edible gum and its constituents are significant and act as thickeners and adhesive agent in pharmaceuticals and industries. Furthermore, it can also be concluded that this medicinal plant is the valuable source of various pharmacologically active phytocompounds, nutritional constituents and certain mineral elements which help in regular physiological functions of the human body. Macro and micro nutrients perform a substantial role in the metabolic activities and formation of certain proteins like hemoprotein and hemoglobin of the body. As the world is become more advanced, the experimental data will provide new leads for researchers to exploit the valuable biological activities including their antimicrobial efficacy and antioxidant activity.

\section{References}

1. Eruvbetine D (2003) Canine Nutrition and Health. A paper presented at the seminar organized by Kensington Pharmaceuticals Nig. Ltd Lagos.

2. Wadhwa N (2015) Textbook of Pediatric Gastroenterology, Hepatology and Nutrition. In: Anupam Sibal Sarath Gopalan (Eds.), Akshay Kapoor Vidyut Bhatia (co-eds). Published by Jaypee Brothers Medical Publishers (P) Ltd New Delhi India First Edition 82(12): 1185-1185.

3. Murray RK, Granner DK, Mayes PA, Rodwell VW (2000) Harper's Biochemistry (25th edtn) McGraw-Hill Health Profession Division USA $8(2)$.

4. Saqib Z, Sultan A (2005) Ethnobotany of Palas valley, Pakistan. Ethnobotanical Leaflets 2005(1): 28 
5. Batra J, Seth PK (2002) Effect of iron defciency on developing rat brain Indian J Clin Biochem 17(2): 108-114.

6. Chakravarty I, Ghosh K (2000) Micronutrient malnutrition present status and future remedies. J Indian Med Assoc 98(9): 539-542.

7. Holroyd KA, Holm JE, Keefe FJ, Turner JA, Bradley LA, et al. (1992) A multi-center evaluation of the McGill Pain Questionnaire: results from more than 1700 chronic pain patients. Pain 48(3): 301-311.

8. Puyravaud JP (2003) Standardizing the calculation of the annual rate of deforestation. Forest Ecology and Management 177(2003): 593-596.

9. Jani GK, Shah DP, Prajapati VD, Jain VC (2009) Gums and mucilages: versatile excipients for pharmaceutical formulations. Asian J Pharm Sci 4(5): 309-323.

10. Verbeken D, Dierckx S, Dewettinck K (2003) Exudate gums: occurrence, production and applications. Applied microbiology and biotechnology 63(1): 10-21.

11. Azarikia F, Abbasi S (2010) On the stabilization mechanism of Doogh (Iranian yoghurt drink) by gum tragacanth. Food Hydrocolloids 24(4): 358-363.

12. Gorji EG, Mohammadifar MA, Ezzatpanah H (2011) Influence of gum tragacanth, Astragalus gossypinus, addition on stability of nonfat Doogh, an Iranian fermented milk drink. International Journal of Dairy Technology 64(2): 262-268.

13. Nejatian M, Hatami M, Mohammadifar MA (2013) Effect of gum tragacanth exuded by three Iranian Astragalus on mixed milk protein system during acid gelation. International journal of biological macromolecules 53: 168-176.

14. Mohammadifar MA, Musavi SM, Kiumarsi A, Williams PA (2006) Solution properties of targacanthin (water-soluble part of gum tragacanth exudate from Astragalus gossypinus). International Journal of Biologica Macromolecules 38(1): 31-39.

15. Ramberg JE, Nelson ED, Sinnott RA (2010) Immunomodulatory dietary polysaccharides: a systematic review of the literature. Nutrition journal 9(1): 54.

16. Tungland BC, Meyer D (2002) Nondigestible oligo-and polysaccharides (Dietary Fiber): their physiology and role in human health and food Comprehensive reviews in food science and food safety 1(3): 90-109.

17. Chen H, Zhang M, Qu Z, Xie B (2008) Antioxidant activities of different fractions of polysaccharide conjugates from green tea (Camellia Sinensis). Food Chemistry 106(2): 559-563.

18. Mestechkina NM, Shcherbukhin VD (2010) Sulfated polysaccharides and their anticoagulant activity: A review. Applied Biochemistry and Microbiology 46(3): 267-273.

19. Li H, Zhang M, Ma G (2010) Hypolipidemic effect of the polysaccharide from Pholiota nameko. Nutrition 26(5): 556-562.

20. Kanekiyo K, Lee JB, Hayashi K, Takenaka H, Hayakawa Y, et al. (2005) Isolation of an Antiviral Polysaccharide, Nostoflan, from a Terrestrial Cyanobacterium, Nostoc f lagelliforme. Journal of natural products 68(7): 1037-1041

21. Ananthi S, Raghavendran HRB, Sunil AG, Gayathri V, Ramakrishnan G, et al. (2010) In vitro antioxidant and in vivo anti-inflammatory potential of crude polysaccharide from Turbinaria ornata (Marine Brown Alga). Food and chemical toxicology 48(1): 187-192.

22. Hamedi A, Farjadian S, Karami MR (2015) Immunomodulatory properties of Trehala manna decoction and its isolated carbohydrate macromolecules. Journal of ethnopharmacology 162: 121-126.

23. Zippel J, Deters A, Pappai D, Hensel A (2009) A high molecular arabinogalactan from Ribes nigrum L. influence on cell physiology of human skin fibroblasts and keratinocytes and internalization into cells via endosomal transport. Carbohydrate research 344(8): 1001-1008.

24. Zhang M, Cui S W, Cheung PCK, Wang Q (2007) Antitumor polysaccharides from mushrooms: a review on their isolation process, structural characteristics and antitumor activity. Trends in Food Science \& Technology 18(1): 4-19.

25. Hamedi A, Ghanati F, Vahidi H (2012) Study on the effects of different culture conditions on the morphology of Agaricus blazei and the relationship between morphology and biomass or EPS production. Annals of microbiology 62(2): 699-707.

26. Smee DF, Sidwell RW, Huffman JH, Huggins JW, Kende M, et al. (1996) Antiviral activities of tragacanthin polysaccharides on Punta Toro virus infections in mice. Chemotherapy 42(4): 286-293.

27. Gelfand HH (1943) The allergenic properties of the vegetable gums: a case of asthma due to tragacanth. Journal of allergy 14(3): 203-219.

28. Graham D (1985) Pattern and control of walking in insects. In Advances in insect physiology Academic Press 18: 31-140. [63] African Pharmacopoeia (1986) OAU/STRC Publication 21: 128-144.

29. (2000) AOAC Official methods of analysis. Washington DC USA: Association of Official Analytical Chemist.

30. (2005) AOAC Official methods of analysis. Washington DC. USA: Association of Official Analytical Chemist.

31. Shahidi F, Chavan UD, Bal AK, McKenzie DB (1999) Chemical composition of beach pea (Lathyrus maritimus L.) plant parts. Food Chem 64(1): 3944.

32. Hassan W, Noreen H, Rehman S, Gul S, Kazmi SNZ, et al. (2014) Nutritional and Phytochemical Profile of One Hundred Medicinal Plants. Journal of Nutritional Ecology and Food Research 2(4): 271-287.

33. Sunggyu L (2005) Encyclopedia of chemical processing. CRC Press 1: 31-33.

34. Hussain J, Rehman NU, Khan AL, Ali L, Al Harrasi A, et al. (2013) Proximate Based Comparative Assessment of Five Medicinal Plants to Meet the Challenges of Malnutrition. European J of Medicinal Plants 3(3): 444-453.

35. Thomas AO, Oyediran OE (2008) Nutritional importance and micronutrient potentials of two non-conventional indigenous green leafy vegetables from Nigeria. Agric j 3(5): 362-365.

36. Sah NK, Kumar S, Subramanian M, Devasagayam TP (1995) Variation in the modulation of superoxide-induced single-strand breaks in plasmid pBR322 DNA by biological antioxidants. Biochemistry and molecular biology international 35(2): 291-296

37. Grinberg LN, Newmark H, Kitrossky N, Rahamim E, Chevion M, et al (1997) Protective effects of tea polyphenols against oxidative damage to red blood cells. Biochemical Pharmacology 54(9): 973-978.

38. Bagchi D, Sen CK, Ray SD, Das DK, Bagchi M, et al. (2003) Molecular mechanisms of cardioprotection by a novel grape seed proanthocyanidin extract. Mutation Research/Fundamental and Molecular Mechanisms of Mutagenesis 523: 87-97.

39. Peterson J, Dwyer J (1998) Flavonoids: dietary occurrence and biochemical activity. Nutrition Research 18(12): 1995-2018.

40. Vesikari T, Matson DO, Dennehy P, Van Damme P, Santosham M, et al. (2006) Safety and efficacy of a pentavalent human bovine (WC3) reassortant rotavirus vaccine. New England Journal of Medicine 354(1): $23-33$.

41. Hazra B, Biswas S, Mandal N (2008) Antioxidant and free radical scavenging activity of Spondias pinnata. BMC complementary and Alternative Medicine 8(1): 63.

42. Singh R, Singh S, Kumar S, Arora S (2007) Evaluation of antioxidant potential of ethyl acetate extract/fractions of Acacia auriculiformis A Cunn. Food and chemical toxicology 45(7): 1216-1223.

43. Doughari JH (2012) Phytochemicals: Extraction methods, basic structures and mode of action as potential chemotherapeutic agents. In Phytochemicals-A global perspective of their role in nutrition and health. InTech. 
44. Han X, Shen T, Lou H (2007) Dietary polyphenols and their biological significance. International Journal of Molecular Sciences 8(9): 950-988.

45. Hussain J, Rehman NU, Khan AL, Hamayun M, Hussain SM, et al. (2010) Proximate and essential nutrients evaluation of selected vegetables species from Kohat region Pakistan. Pak J bot 42(4): 2847-2855.

46. Müller 0, Krawinkel M (2005) Malnutrition and health in developing countries. Canadian Medical Association Journal 173(3): 279-286.

47. Larkin EC, Rao GA (1990) Importance of fetal and neonatal iron: adequacy for normal development of central nervous system. In Brain behaviour and iron in the infant diet. Springer London, p. 43-57.

48. Tan JC, Burns DL, Jones HR (2006) Severe ataxia, myelopathy, and peripheral neuropathy due to acquired copper deficiency in a patient with history of gastrectomy. Journal of Parenteral and Enteral Nutrition. 30(5): 446-450.

49. Wadhwa N (2015) Textbook of Pediatric Gastroenterology, Hepatology and Nutrition: Anupam Sibal, Sarath Gopalan (Eds.), Akshay Kapoor Vidyut Bhatia (Co-Eds.), The Indian Journal of Pediatrics 82(12): 11851185

50. Murray RK, Granner DK, Mayes PA, Rodwell VW (2003) a LANGE medical book. Harper's Illustrated Biochemistry. 26th edition. New York: McGraw-Hill Companies Inc.

51. Sugimoto H, Sawyer DT (1984) Iron (II)-induced activation of hydrogen peroxide to ferryl ion $\left(\mathrm{FeO}^{2+}\right)$ and singlet oxygen (102) in acetonitrile: monoxygenations, dehydrogenations, and dioxygenations of organic substrates. Journal of the American Chemical Society 106(15): 4283 4285 .

\section{ISSN: 2574-1241}

\section{DOI: 10.26717/BJSTR.2019.20.003387}

Waseem Hassan. Biomed J Sci \& Tech Res

(C) This work is licensed under Creative

Submission Link: https://biomedres.us/submit-manuscript.php
52. Reddy MB, Chidambaram MV, Bates GW (1987) Iron transport in microbes, plants and animals. VCH, New York.

53. Hassan W, Rehman S, Noreen H, Gul S, Kazmi SNZ, et al. (2015) Metallic Content of One Hundred (100) Medicinal Plants. J Nutr Disorders Ther 5(177): 2161-0509.

54. Murray RK, Granner DK, Mayes PA, Rodwell VW, Biochemistry HSI, et al. (2003) a LANGE medical book. Harper's Illustrated Biochemistry. $26^{\text {th }}$ ed New York: McGraw-Hill Companies Inc.

55. Zayed AM, Terry N (2003) Chromium in the environment: factors affecting biological remediation. Plant Soil 249(1): 139-156.

56. Cobanoglu U, Demir H, Sayir F, Duran M, Mergan D, et al. (2010) Some mineral trace element and heavy metal concentrations in lung cancer. Asian Pacific journal of cancer prevention: APJCP 11(5): 1383-1388.

57. Tan JC, Burns DL, Jones HR (2006) Severe ataxia myelopathy, and peripheral neuropathy due to acquired copper deficiency in a patient with history of gastrectomy. Journal of Parenteral and Enteral Nutrition, 30(5): 446-450

58. Huheey JE, Keiter EA, Keiter RL (1983) Inorganic chemistry: principles of structure and reactivity. Harper and Row pp. 160-162.

59. We er G, Konie zyński P (2003) Spe iation o Mg, Mn an Zn in extra ts o medicinal plants. Analytical and bioanalytical chemistry 375(8): 10671073.

60. Debrah S, Ayivor J, Denustsui D, Buah-Kwofie A, Forson A, et al. (2011) Elemental evaluation of some herbal plants used in Ghana using INAA. Scholars Research Library 3(5)

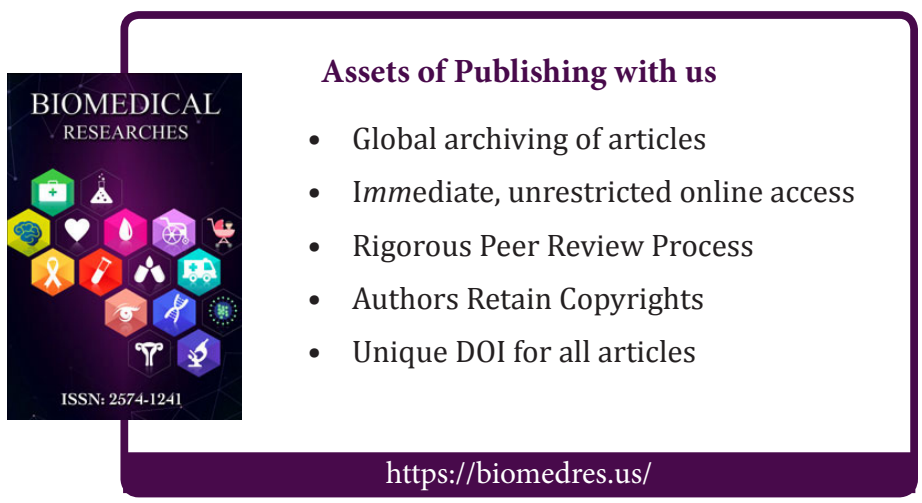

